\title{
DRILL AND PRACTICE SEBAGAI METODE PEMBELAJARAN ALTERNATIF MENINGKATKAN KETERAMPILAN BELAJAR EGRANG SISWA SD
}

\author{
Martiani, Azizatul Banat \\ Fakultas Keguruan Dan Ilmu Pendidikan, Universitas Dehasen Bengkulu \\ Jalan Meranti 32 Bengkulu 38228 \\ annie.phaph@unived.ac.id
}

\section{Article History}

Received: 18 Maret 2020, Accepted: 13 April 2020, Published: 28 Mei 2021

\begin{abstract}
Abstrak
Permainan egrang adalah permainan tradisional khas yang dimainkan di seluruh Indonesia. Bermain ini telah terbukti berkontribusi positif terhadap perkembangan siswa berdasar penelitian yang telah dilakukan sebelumnya. Untuk itu permainan ini harus diajarkan kepada siswa, sehingga siswa mampu bermain secara mandiri atau bersama temannya. Penelitian ini bertujuan untuk mengetahui penerapan drill and practice pada pembelajaran yang dilakukan disekolah. Siswa kelas V SDN 07 Kota Bengkulu sebanyak 23 orang sebagai subjek penelitiannya. Penelitian ini adalah penelitian tindakan kelas (PTK) dengan data didapat melalui empat tahap pada setiap siklus yaitu perencanaan (planning), pelaksanaan (acting), pengamatan (observing) dan refleksi (reflecting). Hasil penelitian didapatkan data dari hasil tes siklus II yaitu rata-rata perolehan nilai keseluruhan yaitu 78.8, nilai maksimal 91, dan nilai minimal 72. Dengan tingkat ketuntasan belajar siswa sebanyak $86.4 \%$ dengan jumlah siswa 20 siswa yang mencapai skor nilai ketuntasan minimum 75 dan yang belum mencapai skor nilai ketuntasan minimum sebanyak 3 orang. Berdasarkan hasil capaian kelas pada siklus II sebesar $86.4 \%$, maka sudah tercapai ketuntasan klasikalnya dan PTK yang dilakukan dianggap sudah berhasil dan pelaksanaan penelitian dihentikan.
\end{abstract}

Keyword: I Drill and Practice; Keterampilan Egrang

\begin{abstract}
The stilts game is a typical traditional game that is played throughout Indonesia. This play has been shown to contribute positively to student development based on previous research. For this reason, this game must be taught to students, so that students are able to play independently or with friends. This study aims to determine the application of drill and practice in learning carried out at school. There were 23 students in grade V SDN 07 Bengkulu City as research subjects. This research is a classroom action research (CAR) with data obtained through four stages in each cycle, namely planning, acting, observing and reflecting. The results of the study obtained data from the results of the test cycle II, namely the average overall score of 78.8, a maximum value of 91, and a minimum value of 72. have not reached the minimum completeness score of 3 people. Based on the results of class achievement in cycle II of $86.4 \%$, classical completeness has been achieved and the CAR is considered successfull and the implementation of the research is stopped.
\end{abstract}

Keyword: Drill and Practic; Egrang Skills 


\section{PENDAHULUAN}

Pembelajaran adalah suatu rangkaian peristiwa yang memengaruhi peserta didik atau pembelajar sedemikian rupa sehingga perubahan perilaku yang disebut hasil belajar terfasilitasi (Suparman, 2012). Senada dengan hal itu, pembelajaran merupakan aktifitas akademik yang berupa interaksi komunikasi antara pendidik dan anak didiknya, proses ini merupakan sebuah tindakan profesional yang bertumpu pada kaidah-kaidah ilmiah (Suhadan, 2010). Aktifitas ini merupakan upaya guru untuk mengaktifkan proses belajar mengajar pebelajar dengan menerapkan berbagai metode belajar. Dalam mengelola pembelajaran terdapat tiga kegiatan dan kemampuan yang harus dikuasai pendidik yaitu, : (1) Kemampuan merencanakan pengajaran, (2) Kemampuan melaksanakan proses pembelajaran, (3) Kemampuan mengevaluasi pembelajaran. Dalam proses pembelajaran guru lebih berperan sebagai motivator dan fasilitator (Suryosubroto, 2009). Guru diharapkan dapat memberikan perangsang, bimbingan dan dorongan kepada siswa agar terjadi proses belajar.

Metode drill adalah suatu aktifitas dalam mengerjakan hal yang sama secara berulang-ulang dan sungguh-sungguh dengan tujuan untuk memperkuat asosiasi atau menyempurnakan keterampilan supaya menjadi permanen (Tambak, 2016). Kegiatan berupa pengulangan berkali-kali dari suatu hal yang sama adalah merupakan ciri yang khas dari metode ini. Drill merupakan kesatuan yang teratur dalam latihan. Metode yang mengarahkan siswa melalui latihan-latihan untuk meningkatkan kecekatan atau ketangkasan dan kefasihan/kelancaran pada sebuah keterampilan. Penanaman kebiasaan tertentu dalam bentuk latihan ditanamkan melalui metode tersebut. Berlatih terus menerus, maka akan tertanam dan kemudian menjadi kebiasaan. Selain untuk pembiasaan, model juga dapat meningkatkan kecepatan, ketepatan, kesempurnaan dalam melakukan sesuatu serta dapat pula dipakai sebagai suatu cara mengulangi bahan latihan yang telah disajikan, juga menambah kecepatan. Model pembelajaran Herbart sebagai pelopor, yaitu model asosiasi dan ulangan tanggapan. Tanggapan pelajaran pada siswa dapat diperkuat melalui model ini. Berbagai mata pelajaran dan kecakapan dapat diajarkan melalui pelaksanaannya secara mekanis.

Pendidikan jasmani, olah raga dan kesehatan (PENJASORKES) merupakan salah satu dari beberapa mata pelajaran yang diselenggarakan di Sekolah. Karakteristiknya berbeda dengan pelajaran lain, perbedaan tersebut meliputi: tujuan pembelajaran yang akan dicapai, prosedur yang harus dilaksanakan dan media yang digunakan. Perencanaan pembelajaran yang matang mengawali sebuah keberhasilan suatu proses pembelajaran. Setengah dari keberhasilan pembelajaran diperoleh dari perencanaan yang dilakukan dengan baik, dan setengahnya lagi terletak pada proses pembelajaran di dalam kelas.

Permainan tradisional merupakan salah satu pokok bahasan yang disajikan pada mata pelajaran PENJASORKES di sekolah. Permainan tradisional adalah permainan yang ada sejak zaman dahulu dengan peralatan yang sederhana dan permainannya mudah dimainkan dan memiliki nilai-nilai keragaman yang tinggi disetiap permainannya. Ada dua syarat permainan olah raga tradisional yaitu berupa "olahraga" dan sekaligus juga "tradisional" baik dalam mempunyai tradisi yang telah berkembang selama beberapa generasi, maupun dalam arti sesuatu yang terkait dengan tradisi budaya suatu bangsa secara lebih luas (Bambang, dkk. 2010).

Egrang atau Batungkau berasal dari kata 'tungkau" yang artinya tinggi, karena permainan ini menjadikan setiap anak yang bermain menjadi tinggi (Muniroh, 2017). Permainan ini dapat dilakukan oleh anak-anak di luar ruangan atau di halaman yang luas. Istilah Egrang atau Engrang sebenarnya adalah tongkat panjang bambu sebagai bahan dasarnya dan dibentuk sedemikian rupa di mana seseorang bisa berdiri di atasnya, kemudian berjalan dalam jarak atau waktu tertentu (Agdini, 2018). Menurut Ningrum, Permainan Egrang merupakan permainan rakyat yang unik dan menyenangkan (Ningrum, 2019). Walaupun sederhana, tetapi sejatinya permainan egrang ini memerlukan keterampilan yang 
mumpuni dalam menjaga keseimbangan tubuh, selain itu ketepatan dan kecepatan juga menjadi kunci dalam permainan tradisional ini. Niat yang sangat kuat diperlukan untuk bermain egrang. Nilai sportivitas bekerja keras, tekun, berani, dan keuletan sangat diperlukan, setiap pemain tidak boleh ragu dan harus menjaga keseimbangan agar tidak terjatuh.

Cara bermain egrang, yaitu (1) Jika alat permainan Egrang sudah disiapkan, pertama-tama pegang egrang dan bersiap menaikan kaki ke atas penyangga, (2) pemain harus bisa menjaga keseimbangan agar tetap bisa bertahan di atas egrang tersebut, (4) ketika kedua kaki sudah naik ke egrang, permain bisa menggerakkan egrangnya ke kanan, ke kiri, atau ke depan, dan berjalan-jalan ke mana saja, dan (5) untuk variasi kegiatan, permainan egrang ini bisa dijadikan perlombaan balapan berjalan dengan menggunakan egrang sehingga akan ada rasa semangat dalam memainkan egrang (Hasanah, dkk. 2016).

Berdasarkan pemaparan studi awal pada SDN 07 Kota Bengkulu menunjukkan bahwa pembelajaran PENJASORKES sudah cukup baik, tetapi pada pembelajaran olahraga tradisional khususnya egrang masih mengalami kesulitan, siswa belum menguasai permainan egrang secara maksimal. Hilangnya keseimbangan saat berada di atasnya, kesulitan untuk melangkahkan kaki, koordinasi tangan dan kaki yang kurang tepat, hingga ketakutan siswa untuk mencoba kembali setelah jatuh. Hal ini dimungkinkan karena proses pembelajaran yang begitu singkat dan repetisi atau pengulangan praktik secara langsung yang sangat terbatas. Berdasarkan keadaan tersebut dirasa perlu untuk melakukan penelitian terhadap pembelajaran menggunakan metode pembelajaran drill yaitu drill and practice sebagai metode pembelajaran alternatif meningkatkan keterampilan belajar egrang siswa SDN 07 Kota Bengkulu.

\section{METODE}

Penelitian Tindakan Kelas (PTK) melalui penerapan metode pembelajaran drill and practice ini dilakukan pada SDN 07 Kota Bengkulu, dengan subjek penelitiannya yaitu siswa yang terdiri dari berbagai macam latar belakang agama, suku dan kebiasaan, pekerjaan orang tua dan kemampuan ekonomi sehingga akan berdampak pada kemampuan dan keterampilan anak dalam mengikuti dan melaksanakan tugas belajar yang harus dicapai siswa sesuai dengan kurikulum yang digunakan.

Prosedur penelitian pada tahap ini yaitu Perencanaan (Planning), Pelaksanaan (Acting), Pengamatan (Observing) dan Refleksi (Reflecting)berdasar pernyataan Arikunto (2010). Tahapan perencanaan atau planning meliputi pengembangan perangkat pembelajaran, persiapan sarana dan prasarana penelitian, indikator kerja yang telah ditentukan serta instrumen pengamatan. Tahapan pelaksanaan tindakan atau acting meliputi implementasi segala tindakan yang tertuang dalam Rencana Pelaksanaan Pembelajaran (RPP). Hal yang perlu diperhatikan pada tahap ini adalah pembelajaran harus berjalan seperti biasanya. Pengamatan secara objektif dilakukan oleh kolaborator sesuai kondisi pembelajaran yang dilakukan peneliti. Tahap pelaksanaan ini sangat penting karena tujuan PTK adalah untuk memperbaiki proses pembelajaran. Tahapan pengamatan atau observasi ini dilakukan bersamaan dengan dilaksanakannya tindakan. Pada tahap pengamatan terdapat dua kegiatan yang akan diamati, yaitu kegiatan belajar peserta didk dan kegiatan pembelajaran. Kolaborator setelah selesai melakukan kegiatan pengamatan pembelajaran maka merefleksikan kembali bersama peneliti atas aktifitas pembelajaran yang telah dilaksanakan. Diskusi merupakan kegiatan refleksi yang dilakukan oleh kolaborator dengan guru pelaksana (peneliti).

Data egrang yang dibutuhkan dalam penelitian ini yaitu data yang didapat melalui tes keterampilan bermain egrang sejauh 50 Meter. Perlengkapan yang digunakan yaitu: (1) Egrang bambu dengan ukuran standar anak-anak, (2) Lapangan datar sesuai ukuran standar yaitu panjang 50 Meter dan lebar 7.5 Meter yang dibagi kedalam 5 lintasan. Lebar lintasan bisa disesuaikan, (3) Tali atau kapur 
sebagai garis lintasan, (4) Form penilaian, (5) ATK, (6) Meteran, (7) Bendera dan peluit, (8) Pengawas lintasan, dan (9) Cones (Wiranata et al., 2019).

Adapun pelaksanaannya yaitu: (1) menggunakan aba-aba "bersedia", "siap" dan "ya", aba-aba "ya" boleh diganti dengan tiupan peluit dan atau disertai bendera. Sebelum dilakukan aba-aba teste berdiri dengan jarak 1 meter dibelakang garis start dan memegang egrang yang akan digunakan. (2) Aba-aba "bersedia" testee memajukan egrang mendekati garis start dengan memegang kedua egrang dan kedua kaki belum menaiki egrang. (3) Aba-aba "siap" testee menaikkan satu kaki (kanan atau kiri) pada pijakan egrang. (4) Aba-aba "ya" atau peluit testee langsung menaikkan satu kaki yang lain dan bersegera berjalan atau berlari dengan menggunakan egrang dengan jarak lintasan sejauh 50 Meter. (5) Jika testee terjatuh dan jarak yang belum ditempuh masih panjang (dalam jarak 50 meter), maka diperbolehkan untuk melanjutkan kembali dan tempat testee terjatuh langsung diberi tanda oleh pengawas lintasan guna diukur jarak perjalanannya. (6) Jarak yang diambil dalam 1 kali tes diambil dari jarak tempuh terjauh setelah terjatuh dan memulai kembali. (7) Testee diberikan kesempatan sebanyak 2 kali tes, nilai testee diambil nilai terbaik dari tes dengan jarak tempuh terjauh yang dikali dua.

\section{HASIL}

Data hasil belajar siswa dimulai dari pra siklus, siklus I dan siklus II. Pada setiap siklus mempunyai bagian-bagian yang sama yaitu dimulai dari perencanaan, dilajutkan dengan pelaksanaan tindakan, pengamatan (observasi), lalu diakhiri dengan refleksi.

Hasil penelitian pada siklus I didapatkan data dari hasil tes siklus I yaitu rata-rata perolehan nilai keseluruhan yaitu 69.3, nilai maksimal 80, dan nilai minimal 54. Dengan tingkat ketuntasan belajar siswa sebanyak $39.1 \%$ dengan jumlah siswa yang mencapai skor nilai ketuntasan minimum 75 sebanyak 9 orang dan yang belum mencapai skor nilai ketuntasan minimum sebanyak 14 orang. Untuk lebih jelasnya akan disajikan dalam grafik 1 hasil belajar siswa pada siklus I.

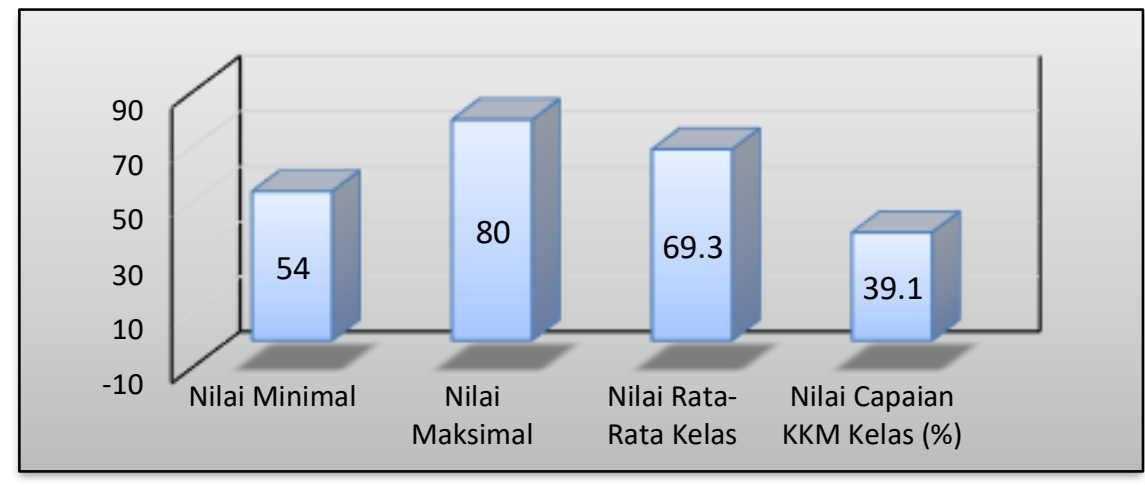

Grafik 1. Data Hasil Penelitian Siklus satu.

Hasil penelitian pada siklus I didapatkan data dari hasil tes siklus II yaitu rata-rata perolehan nilai keseluruhan yaitu 78.8, nilai maksimal 91, dan nilai minimal 72. Dengan tingkat ketuntasan belajar siswa sebanyak $86.4 \%$ dengan jumlah siswa yang mencapai skor nilai ketuntasan minimum 75 sebanyak 20 orang dan yang belum mencapai skor nilai ketuntasan minimum sebanyak 3 orang. Untuk lebih jelasnya akan disajikan dalam grafik 2 hasil belajar siswa pada siklus II. 


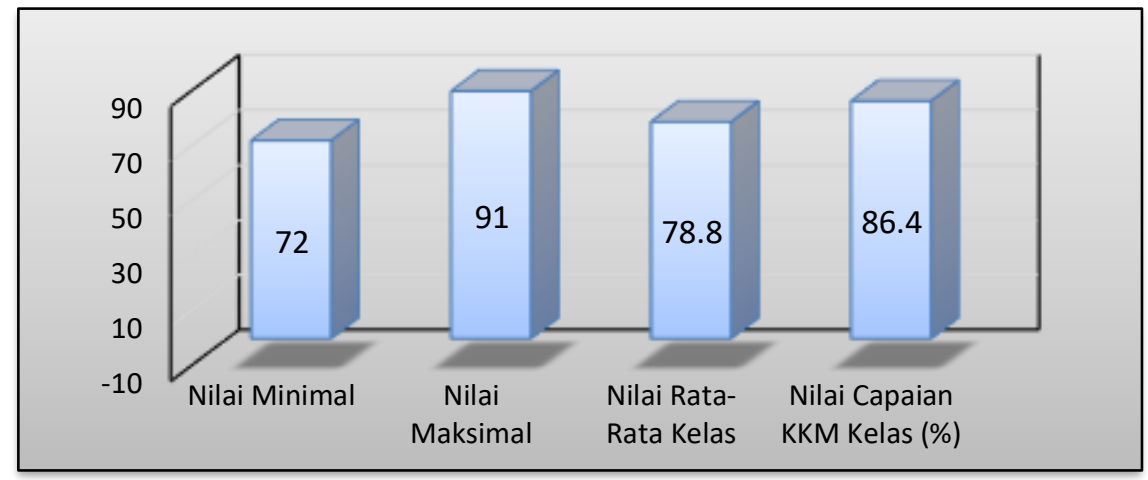

Grafik 2. Data Hasil Penelitian Siklus dua

PTK dilakukan dengan jumlah sampel sebanyak 23 orang di kelas V SDN 07 Kota Bengkulu menunjukkan bahwa penerapan metode belajar drill pada pembelajaran olahraga tradisional egrang sangat membantu siswa dalam menyelesaikan tugas belajarnya dengan baik, hal ini dibuktikan dengan nilai belajar siswa yang telah mencapai nilai minimum mata pelajaran yaitu dengan nilai rata-rata kelas 78.8 .

\section{PEMBAHASAN}

Pada awal pembelajaran siklus I siswa sebanyak 14 orang mengalami kesulitan pada proses menaiki egrang dan melangkah untuk berjalan untuk pertama kalinya, hanya ada beberapa siswa berjumlah 9 orang saja yang sudah bisa melakukan hal itu dengan lancar karena ternyata sebelumnya sudah pernah belajar dirumah. Namun para siswa yang masih mengalami kendala ini begitu antusias dalam mengikuti proses pembelajaran dengan semangat. Selanjutnya, dengan motivasi, arahan dan latihan yang dilakukan memberikan dampak positif pada siswa dalam proses belajar mereka, untuk menguasai suatu keterampilan baru (Bai et al., 2020; Luik, Piret;Marandi, 2003; Viegas et al., 2021). Hasil belajar siswa yang mencapai nilai KKM mata pelajaran PENJASORKES yaitu 75, berjumlah 11 siswa dari total kelas 23 siswa. Hal ini berarti hanya $47.8 \%$ kelas yang sudah mendapatkan nilai tuntas. Belum tercapainya ketuntasan klasikal kelas $85 \%$ dalam PTK inilah yang menjadi dasar untuk melanjutkan penelitian pada siklus II.

Pembelajaran siklus II dilaksanakan berdasarkan refleksi yang telah dilakukan pada siklus I. Pembelajaran berfokus pada siswa yang belum mencapai KKM untuk semangat dan terus berlatih hingga mencapai nilai KKM dan didapatkan kategori tuntas. Pembelajaran pada siklus I sama dengan pembelajaran pada siklus II, hal ini dimaksudkan agar siswa dapat berkerjasama, saling membantu dan memiliki tanggungjawab dan beban yang sama, bedanya yaitu jika pada siklus I pemilihan siswa dalam kelompok dilakukan secara acak, tetapi pada siklus II ini pemilihan siswanya dibagi berdasarkan siswa yang sudah bisa melakukan dan mendapat nilai tuntas, selanjutnya siswa yang lain mengikuti. Hal ini dimaksudkan agar siswa yang sudah bisa dan tuntas pada siklus I dapat difungsikan menjadi leader pada kelompok kecilnya dan membantu anggota yang lain.

Hasil yang diperoleh pada pembelajaran siklus II menunjukkan adanya peningkatan jumlah siswa yang mencapai nilai KKM kelas yaitu 75. Siswa yang memperoleh nilai tuntas yaitu sebanyak 20 dari total keseluruhan 23 siswa. Hal ini berarti ketuntasan kelas mencapai 86.9\%, dengan capaian tersebut juga telah mencapai standar ketuntasan klasikal pada jenis penelitian tidakan kelas yang digunakan. PTK ini dapat dinyatakan selesai dan berhasil meningkatkan nilai hasil belajar siswa pada siklus II.

Pada penggunaan alat egrang, sebelumnya egrang yang digunakan siswa yaitu egrang yang dibuat tanpa adanya standar ukuran, sehingga anak-anak dan dewasa pun menggunakan egrang yang ukurannya sama. Akibatnya anak-anak yang tinggi badannya relatif rendah mengalami kesulitan saat akan menaiki 
pijakan egrang yang tinggi dan tidak sesuai dengan tinggi badannya. Pada pembelajaran drill, egrang yang digunakan siswa harus mengikuti ukuran standar nasional yaitu untuk siswa kelas $\mathrm{V}$ sekolah dasar yang rata-rata pada usia 12 tahun menggunakan egrang dengan ketinggian pijakan $50 \mathrm{~cm}$ (Siahaan, 2013).

Selama dilaksanakannya pembelajaran olahraga tradisional egrang dengan menggunakan metode latihan drill, siswa mengikuti pembelajaran dengan tertib sesuai dengan instruksi yang diberikan. Pembelajaran dilaksanakan dengan cara berkelompok, siswa dibagi menjadi 5 kelompok. Setelah dijelaskan dan diberi contoh, siswa langsung mempraktikkan tugas gerak didalam kelompoknya masingmasing dan bertanggungjawab untuk membantu teman yang belum bisa melakukan. Metode latihan drill diterapkan bertujuan untuk melatih siswa agar mencapai nilai terbaik mereka dengan melakukannya berulang-ulang dan terus menerus, dengan demikian konsep, keterampilan, dan kompetensi dapat dicapai (Merrill et al., n.d.; Rathakrishnan et al., 2018).

Semangat belajar dan kerja keras juga ditunjukkan siswa dengan cara belajar terus-menerus di dalam kelompok belajarnya, saling berdiskusi, tanya jawab dan saling membantu (Deen et al., n.d.; Gee \& Umar, 2014). Ketika salah satu anggota kelompoknya mempraktikkan maka teman yang lain membantu dengan cara memegang egrang kemudian secara perlahan melepaskan untuk selanjutnya menjaga keseimbangan (Laely \& Yudi, 2015; Rahim, 2015). Siswa yang sudah bisa menaiki egrang maka akan berfokus latihan untuk jalan cepat atau berlari pada jarak tempuh 50 meter (Haris, 2017).

Pembelajaran olahraga tradisional egrang selama ini dilakukan dengan menggunakan buku pelajaran yang ada tanpa memadukan dengan komponen lain yang sengaja didesain untuk menarik perhatian dan minat belajar siswa. Kegiatan siswa yang dapat diamati dalam proses pembelajaran siklus II, dapat mengasah keterampilan dan meningkatkan kemampuan mereka. Siswa mulai mengerti bagaimana menggunakan engrang dengan baik dan berjalan menggunakannya, secara bertahap proses mereka belajar secara langsung membuktikan bahwa pengalaman belajar secara langsung diperlukan sesuai dengan kerucut pengalaman (Dale, 1969). Dengan adanya penerapan metode drill ini, pembelajaran disusun sedemikian rupa berdasarkan referensi buku dan penelitian sehingga pembelajaran menjadi menarik dan disesuaikan dengan usia siswa.

Permainan egrang merupakan permainan tradisional yang tumbuh dan berkembang di seluruh Indonesia, terbukti bahwa penelitian bertema permainan ini tersebar di seluruh ruang publikasi ilmiah nasional. Artikel terpublikasi terdiri dari penelitian kualitatif, kuantitatif, penelitian dan pengembangan dan ethnografi. Topik penelitian yang melibatkan permainan egrang ini meliputi metode pelatihan, pengaruh pelatihan, keterampilan motorik, pemanfaatannya maupun pengembangannya.

Egrang merupakan jenis permainan yang terbuat dari bahan sederhana yang ada di alam, baik dari batok kelapa (tempurung) (Andrian \& Ehan, 2017; Siahaan, 2013) maupun bambu (Hikmah, 2011). Egrang yang dikembangkan dari batok kelapa, berdasarkan penelitian sebelumnya mampu melatih motorik pada siswa berkebutuhan khusus maupun anak usia dini (Andrian \& Ehan, 2017; Siahaan, 2013). Beberapa penelitian juga mengungkapkan bahwa bermain egrang mampu melatih keseimbangan tubuh (Haris, 2017; Rahim, 2015; Yusup, 2013). Bermain egrang juga mampu meningkatkan kepercayaan diri anak usia dini (Munir, 2019) dan mengembangkan kecerdasan kinestetik (Laely \& Yudi, 2015; Lahay, 2013). Perilaku hiperaktif pada anak penderita autis juga mampu dikurangi dengan permainan ini seperti yang dilaporkan oleh (S K Sari, 2014)

Drill and practice merupakan upaya untuk memfasilitasi pembelajaran. Tujuannya adalah membantu pebelajar untuk berlatih lancar dan ketahanan ingatan (Alessi \& Trollip, 2001). Metode ini menyediakan pengulangan-pengulangan bahan yang dipelajari atau dilatihkan sampai berhasil tanpa melakukan kesalahan atau tuntas. Kecepatan merupakan hal yang melingkupi dari drill ini, sehingga 
setelah penyajian informasi, latihan dilakukan untuk menyelesaikan permasalahan dengan cepat dan ini menunjukkan kelancaran penguasaannya.

Dalam proses pembelajaran, drill and practice merupakan tahap ketiga yaitu practicing (berlatih) setelah pebelajar meneriman panduan dalam mempelajarinya dan menerima informasi. Selama ini drill and practice banyak dilakukan untuk kecakapan bahasa dan keterampilan motorik. Pembelajaran kecakapan bahasa yaitu dengan mengembangkan multimedia interaktif drill and practice atau pada kompetensi tertentu dilakukan berlatih secara fisik. Beberapa artikel menyajikan pengembangan multimedia drill and practice dengan tahap yang sama dalam proses pembelajarannya (Gunawan et al., 2020; Lestari et al., 2020; R. V. Sari, Sulton, et al., 2020). Belum ada artikel yang memberikan informasi tentang metode drill and practice untuk meningkatkan keterampilan egrang. Dengan demikian pengembangan metode drill and practice ini memberikan kontribusi positif terhadap peningkatan keterampilan bermain egrang.

\section{SIMPULAN}

PTK pada siswa kelas V SDN 07 Kota Bengkulu yang dilaksanakan dalam 2 siklus. Setiap siklusnya terdiri atas empat tahapan, yaitu perencanaan, pelaksanaan tindakan, observasi, dan refleksi. Berdasarkan hasil penelitian dan pembahasan maka dapat disimpulkan bahwa metode pembelajaran drill and practice dapat meningkatkan hasil belajar siswa pada olahraga trasidional egrang. Hasil penelitian pada siklus II didapatkan data dari hasil tes siklus II yaitu rata-rata perolehan nilai keseluruhan yaitu 78.8, nilai maksimal 91, dan nilai minimal 72. Dengan tingkat ketuntasan belajar siswa sebanyak $86.4 \%$ dengan jumlah siswa yang mencapai skor nilai ketuntasan minimum 75 sebanyak 20 orang dan yang belum mencapai skor nilai ketuntasan minimum sebanyak 3 orang. Berdasarkan hasil capaian kelas pada siklus II sebesar $86.4 \%$, maka ketuntasan klasikal sudah tercapai dan PTK yang dilakukan dianggap sudah berhasil dan pelaksanaan penelitian dihentikan pada siklus ke II.

\section{DAFTAR RUJUKAN}

Agdini, Nurul. (2018). Egrang, Permainan Sekaligus Olahraga Tradisional Indonesia. https://id.wikipedia.org/wiki/Egrang

Alessi, S. M., \& Trollip, S. R. (2001). Multimedia for learning: Methods and development. Allyn \& Bacon.

Arikunto, Suharsimi. (2010). Prosedur Penelitian Suatu Pendekatan Praktis. Yogyakarta: Rineka Cipta.

Andrian, I. L., \& Ehan. (2017). Egrang batok untuk melatih keterampilan motorik kasar siswa tunanetra. JASSI Anakku, 18(2), 29-34.

Bai, B., Wang, J., \& Nie, Y. (2020). Self-efficacy, task values and growth mindset: What has the most predictive power for primary school students' self-regulated learning in English writing and writing competence in an Asian Confucian cultural context? Cambridge Journal of Education, 51(1), 1-20. https://doi.org/10.1080/0305764X.2020.1778639

Deen, M., ... A. V. den B.-I. J. of, \& 2015, undefined. (n.d.). The differences between problem-based and drill and practice games on motivations to learn. Igi-Global.Com.

Gee, Y. T., \& Umar, I. N. (2014). The Effects of Drill and Practice Courseware on Students ' Achievement and Motivation in Learning. World Academy of Science, Engineering and Technology-International Journal of Educational and Pedagogical Sciences, 8(12), 3614-3619.

Gunawan, F., Soepriyanto, Y., \& Wedi, A. (2020). Pengembangan Multimedia Drill And Practice Meningkatkan Kecakapan Bahasa Jepang Ungkapan Sehari-Hari. JKTP: Jurnal Kajian Teknologi Pendidikan, 3(2), 187-198. https://doi.org/10.17977/um038v3i22020p187 
Haris, I. N. (2017). Pengaruh Latihan Egrang Dan Gobag Sodor Terhadap Keseimbangan Tubuh Pada Siswa Sdn 1 Subang. Jurnal Penjaskesrek, 4(2), 163-178.

Hikmah, M. A. (2011). Perancangan game tradisional jawa egrang bambu. (Not published) [Skripsi]. Universitas Negeri Malang.

Laely, K., \& Yudi, D. (2015). Pengaruh permainan egrang tempurung kelapa terhadap peningkatan kecerdasan kinestetik anak. EMPOWERMENT: Jurnal Ilmiah Program Studi Pendidikan Luar Sekolah, 4(1), 32-41.

Lahay, R. (2013). Mengembangkan Kecerdasan Kinestetik Melalui Permainan Egrang Pada Anak Kelompok B TK Garuda Desa Huluduotamo Kecamatan Suwawa Kabupaten Bone Bolango. (Skripsi, not published). [Skripsi]. Universitas Negeri Gorontalo.

Lestari, K., Soepriyanto, Y., \& Husna, A. (2020). Multimedia Drill And Practice Belajar Kosa Kata Bahasa Jepang Untuk Siswa Lintas Minat. JKTP: Jurnal Kajian Teknologi Pendidikan, 3(4), 415424. https://doi.org/10.17977/um038v3i42020p415

Luik, Piret;Marandi, T. (2003). Are drill-and-practice programs for everyone?

Merrill, P., Instruction, D. S.-J. of C.-B., \& 1984, undefined. (n.d.). Research on drill and practice strategies. Learntechlib.Org.

Munir, A. (2019). Pengaruh Permainan Balap Karung dan Egrang terhadap Peningkatan Kepercayaan Diri Anak Usia Dini di PAUD Cahaya Kecamatan Rambutan Kota Tebing Tinggi. JURNAL DIVERSITA, 5(2), 161-172. https://doi.org/10.31289/diversita.v5i2.3056

Rahim, A. F. (2015). Pengaruh permainan tradisional egrang tempurung kelapa terhadap keseimbangan anak usia dini 4-6 tahun. Universitas Muhammadiyah Surakarta.

Rathakrishnan, M., Raman, A., \& Haniffa, M. A. (2018). The Drill and Practice Application in Teaching Science for Lower Secondary Students. In Researchgate.net.

Sari, R. V., Sulton, S., \& Soepriyanto, Y. (2020). Pengembangan multimedia drill and practice untuk meningkatkan kemampuan vocabulary bahasa jepang. 4(1), 12.

Sari, S K. (2014). Mengurangi perilaku hiperaktif pada anak autis melalui permainan tradisional egrang di slb negeri kota pariaman. E-JUPEKhu (Jurnal Ilmiah Pendidikan Khusus), 3(1), 276-284.

Siahaan, H. (2013). Peningkatan kemampuan motorik kasar anak usia dini melalui metode bermain egrang batok kelapa di RA-Alhidayah Medan. UNIMED.

Viegas, Â. A., Mendonça, V. A., Pontes Nobre, J. N., Souza Morais, R. L. De, Fernandes, A. C., Oliveira Ferreira, F. De, Scheidt Figueiredo, P. H., Leite, H. R., Resende Camargos, A. C., \& Rodrigues Lacerda, A. C. (2021). Associations of physical activity and cognitive function with gross motor skills in preschoolers: Cross-sectional study. Journal of Motor Behavior, 1-16. https://doi.org/10.1080/00222895.2021.1897508

Wiranata, Y., Sugihartono, T., \& Ilahi, B. (2019). Kontribusi Keseimbangan Dan Koordinasi Mata Tangan-Kaki Terhadap Keterampilan Permainan Egrang Di SMAN 2 Kota Bengkulu. Repository.Unib.Ac.Id.

Yusup, K. (2013). Pengaruh permainan egrang dalam pembelajaran pendidikan jasmani terhadap keseimbangan siswa sma pgii 2 bandung (not published) [Dissertation]. UPI. 